\title{
How to improve teaching in family medicine
}

\author{
Sanda Pribić, Rudika Gmajnić \\ Department of Family Medicine at the \\ Faculty of Medicine, Osijek, Croatia \\ Corresponding author: \\ Sanda Pribić \\ Dom zdravlja Osijek \\ Park kralja Petra Krešimira IV, No 6 \\ Osijek \\ Croatia \\ sanda.pribic@os.t-com.hr \\ Tel.: + 38531225400 \\ Fax: + 38531225330
}

Received: 9 February 2012

Accepted: 19 April 2012

Copyright (C) 2012 by

Academy of Sciences and Arts

of Bosnia and Herzegovina.

E-mail for permission to publish:

amabih@anubih.ba

\begin{abstract}
The family physician has a specific task and responsibility as the first contact physician. Therefore his/her education needs to be highly specific, oriented towards independent work in real time and evidencebased medical principles. The most important role in educating a family physician belongs to physician practitioners, individuals who work in clinics and need (as much as possible) to transfer knowledge, skills and experiences from their own specific conditions and a wide variety of work methods. Therefore the experience and suggestions of teachers in practical training are considered to be the most significant contribution to improving the quality of teaching. The most important suggestions pertain to reducing the size of seminar groups, including family medicine courses in the fourth and fifth year of studies, and increasing the possibilities for students to do independent work, with supervision by their mentors. For good preparation of future physicians for independent work it is necessary for family medicine departments to be able to organize practical training and seminars in as many courses as possible, with as many classes as possible. A good professional basis in terms of selected teachers and practical training teachers is required to make this possible.
\end{abstract}

Key words: Family medicine, Education, Teaching.

\section{Introduction}

The education of family medicine physicians (FMPs), due to their specific role, position and work methods, requires a quite different form of education than is the case for preclinical or clinical physicians (1). Given the role of FMPs as first contact physicians, the gatekeepers to the health care system, those who are entrusted with the task of solving up to $80 \%$ of all the health problems in the population $(2,3)$, specific education must be oriented toward realistic and practical work with patients. FMPs must learn how to function independently and make decisions, but they must also be able to communicate and cooperate with their fellow consultants, specialists, the family and other members of the community $(4,5)$.

\section{The experience of family physicians as teachers}

Teaching in family medicine in Osijek began in 1980, when the Medical Studies Department of the Faculty of Medicine of the University in Zagreb was formed. According to the syllabus at the time, the family medicine course was part of the 5th (final) year 
of the studies, with a relatively small number of lectures and seminars, and especially few practical training classes (15 lectures, 30 seminars, 20 practical classes). During the Homeland War in 1991, the Medical Studies Department was relocated back to the parent faculty at the University in Zagreb $(6,7,8)$. In spite of that, primary health care in Slavonia and Baranja continued to operate adequately and efficiently. As part of the organization of the Osijek Health Centre (Dom zdravlja Osijek) and the Department of Family Medicine $(9,10)$ the 1992/1993 academic year began with regular classes in Osijek, still as part of the Medical Studies Department of the Faculty of Medicine of Zagreb University. In 1995 the Faculty of Medicine was founded at the J. J. Strossmayer University, and at that time education in family medicine improved significantly, in terms of quantity (25 lectures, 35 seminars and 50 practical classes) and quality (there were 10 new assistants and 2 lecturers involved in the teaching). The new syllabus of 2003 introduced an even more significant increase in the number of lectures (25 lectures, 55 seminars, 100 practical classes), and on the basis of the latest syllabus (for 2011) the Department of Family Medicine offers 65 hours of practical training (Table 1).

In the last 15 years, family medicine has undergone several thorough reforms and changes, primarily in terms of legislation and organization. In 1997 the majority of physicians were given the status of tenants, which significantly diminished the ability of the Health Centre to coordinate these teams professionally. The payment system, which was mostly based on a "head count" (payment per patient) enabled some of the doctors to realize significant income by accumulating a large number of patients, to the detriment of the quality of the medical service provided. Due to these changes, in teaching

Table 1 Courses held by teachers at the Department of Family Medicine of the Faculty of Medicine in Osijek

\begin{tabular}{|c|c|c|c|c|c|}
\hline Course & Status & $\begin{array}{l}\text { Practical } \\
\text { classes (hours) }\end{array}$ & $\begin{array}{l}\text { Seminars } \\
\text { (hours) }\end{array}$ & $\begin{array}{l}\text { Lectures } \\
\text { (hours) }\end{array}$ & $\begin{array}{l}\text { Total } \\
\text { (hours }\end{array}$ \\
\hline $\begin{array}{l}\text { Family medicine, school medicine and medical } \\
\text { sociology }\end{array}$ & Regular & $\begin{array}{l}100+65 \text { in the } \\
\text { skills laboratory }\end{array}$ & 55 & 25 & 245 \\
\hline $\begin{array}{l}\text { Economics of health and organization of health } \\
\text { care }\end{array}$ & Regular & 10 & 20 & 15 & 45 \\
\hline Inter-sector cooperation & Elective & 10 & 10 & 5 & 25 \\
\hline How to apply the Hippocratic Oath & Elective & - & 25 & - & 25 \\
\hline Physicians as employers & Elective & 10 & 10 & 5 & 25 \\
\hline Medicine and the Health Law & Regular & 2 & 15 & 8 & 25 \\
\hline Occupational medicine & Regular & 10 & 5 & 5 & 20 \\
\hline $\begin{array}{l}\text { Introduction to the work of a family medicine } \\
\text { clinic }\end{array}$ & Regular & 18 & 7 & - & 25 \\
\hline $\begin{array}{l}\text { Program of prevention measures and early } \\
\text { detection of some of the most frequent cancer } \\
\text { sites }\end{array}$ & Elective & 8 & 10 & 7 & 25 \\
\hline Promotion of health and primary health care & Elective & 15 & 15 & 30 & 60 \\
\hline Management in health care & Elective & 8 & 10 & 7 & 25 \\
\hline Social and health legislation & Elective & 8 & 10 & 7 & 25 \\
\hline Total & & 264 & 192 & 114 & 570 \\
\hline
\end{tabular}


students it was necessary to show them the large number of specificities and possibilities which they could expect in their practice. They need to be able to function independently as: physicians as employees of the Health Centre, physicians as tenants, physicians in an urban area, physicians in a rural area, physicians in a group practice, teachers providing practical training for students, as assistants and supporting the teaching/ education of medical students. All the above demonstrates the major organizational and executive problems involved in running the courses. The Medical Faculty in Osijek has given the Department of Family Medicine a large number of teaching hours. A great deal of support for the lectures has been given by all family medicine physicians, through guiding students in their exercises and work in their clinics. In all the surveys undertaken students have reported that it was only during the course in family medicine that they were given the possibility of working independently and making decisions (with the guidance of their mentors) (11).

\section{The position of family physicians in Slavonia, Croatia}

I (Sanda Pribić) have worked as a family physician for 17 years, 7 of which as a family medicine specialist. In the meantime I have completed two postgraduate studies and a $\mathrm{PhD}$, defended my doctoral thesis and started my scientific and teaching career. The clinic in which I work is a town clinic, and a polyvalent one. I care for 1780 patients of all age groups. Half of the patients are elderly, so in our work at the clinic we have organized groups for chronic patients, for patients suffering from diabetes, hypertension and a group for obese patients. Working with a group of patients requires an interactive exchange of knowledge and experience, and it significantly simplifies routine work at the clinic. House calls and treatment at the patients' homes is a regular part of the practice, and it is also how I see the role of the family physician in the life of the patients and their families.

The teaching organized by the Department of Family Medicine at the Faculty of Medicine in Osijek is organized with the aim of preparing the students in their last year of studies, as they are soon to be independent physicians, for independent work and decision-making. Therefore the Department of Family Medicine has been given the privilege and responsibility to organize the courses presented in Table 1.

In the preparation and realization of all courses we specifically aim to: detect the current issues and deal with them practically and scientifically, detect local, specific issues, involve local co-workers who are renowned experts in their field, encourage practical training teachers, as excellent practitioners, to selflessly share their knowledge and skills, to enable the students to recognize and independently solve the assigned problem cases regarding the health and illness of individuals, the family and the community. Clinical skills and solving real problems become the focus of the students' interests.

\section{Experiences of family physicians as teachers}

In spite of my experience, practical work and continuous participation in teaching, I still encounter problems and obstacles in organizing the education of future family medicine physicians. On the "Family Medicine" course the students in their last year of studies come unprepared for practical work and with great lack of communication skills. The overall concept of studying and learning at the Faculty of Medicine is oriented towards acquiring facts and theoretical knowledge. It is extremely rare for students to become involved in more serious work during their practical training. The 
exams are designed either as endless written questions with learned answers, or as tests of one's knowledge in oral exams. Hardly anyone requires the students to show problem-solving skills and apply principles of evidence based medicine $(12,13,14,15)$. In their last year of studies the students begin to feel like our future colleagues, and look in panic for possibilities to learn more about the practical work which they will soon be engaged in. Therefore practical training in family medicine clinics is most often the first and last chance for future physicians to learn to think and act in real time. A special problem and shortcoming of the studies relates to communication skills. Communication with patients, with colleagues and the community is an important element in work in family medicine. From taking a medical history to the moment when a patient or family needs to be given some important news or information, very subtle communications skills are required. Our experiences have yielded numerous suggestions which may improve the system of teaching family medicine (Table 2).

\section{Suggestions for improving teaching}

Family medicine physicians, practitioners, as teachers of practical training can significantly contribute to the organization of lessons, and to that end, suggest significant improvements (Table 2). Some of the

Table 2 Suggestions for improving teaching

\begin{tabular}{|c|c|}
\hline Suggestions & Explanation \\
\hline Minimize the number of lectures. & $\begin{array}{l}\text { Lectures are normally rated as "boring" and they do not } \\
\text { provide enough possibilities for independent work. }\end{array}$ \\
\hline Organize seminars in smaller groups. & $\begin{array}{l}\text { Seminar groups of } 20 \text { students are inefficient. Groups need to } \\
\text { reduced to } 4-6 \text { students. }\end{array}$ \\
\hline Problem solving assignments. & $\begin{array}{l}\text { The theoretical knowledge has already been acquired. It is } \\
\text { necessary to learn to solve real problems and tasks. }\end{array}$ \\
\hline $\begin{array}{l}\text { Organize small groups of students }(2-4) \text { who would, in } \\
\text { real time and space, design a concept of diagnostics, } \\
\text { treatment and rehabilitation for certain conditions or } \\
\text { illnesses. }\end{array}$ & $\begin{array}{l}2-4 \text { students in the family medicine clinic can actively } \\
\text { participate in its work. After the adjustment period they } \\
\text { would be given the opportunity to work independently. }\end{array}$ \\
\hline Encourage round tables and panel discussions. & $\begin{array}{l}\text { Exchange of experiences and information between students } \\
\text { who have taken part in practical training in clinics in different } \\
\text { places and different conditions. }\end{array}$ \\
\hline $\begin{array}{l}\text { Significantly increase the number of hours of practical } \\
\text { training. }\end{array}$ & $\begin{array}{l}\text { By repeated possibilities for practical work one can reach the } \\
\text { level of independent decision-making. }\end{array}$ \\
\hline $\begin{array}{l}\text { Use a system of elective courses to increase interest in } \\
\text { family medicine issues }\end{array}$ & $\begin{array}{l}\text { Insufficient number of classes and inadequate program of } \\
\text { regular courses need to be replaced by targeted elective } \\
\text { courses. }\end{array}$ \\
\hline $\begin{array}{l}\text { Integrate some elements of family medicine teaching in } \\
\text { the 4th, 5th and 6th years of studies. }\end{array}$ & $\begin{array}{l}\text { Family medicine as a practical discipline must be taught at } \\
\text { least in the } 4 \text { th, } 5 \text { th and } 6 \text { th years of studies. }\end{array}$ \\
\hline Encourage students' involvement in scientific research. & $\begin{array}{l}\text { In family medicine it is not only possible, but also necessary } \\
\text { and valuable, to be involved in scientific research. }\end{array}$ \\
\hline $\begin{array}{l}\text { Define the role and subject matter which the work of } \\
\text { mentors and teachers of practical training. }\end{array}$ & $\begin{array}{l}\text { They are the most important teachers, because they transfer } \\
\text { knowledge, experiences and skills on a personal level. }\end{array}$ \\
\hline $\begin{array}{l}\text { Insist on adequate evaluation of the work of all } \\
\text { participants in teaching. }\end{array}$ & This involves financial, professional and moral stimulation. \\
\hline $\begin{array}{l}\text { Continuously educate teachers, mentors and teachers of } \\
\text { practical training. }\end{array}$ & This is a necessity. \\
\hline
\end{tabular}


suggested improvements might be applied instantly because they do not require any significant organizational or financial alterations. All teachers of practical training claim that there is a need to continuously educate teachers, mentors and teachers of practical training (16).

By obstinately insisting on improvements, inter-departmental cooperation and promotion of our own values, we can assert ourselves as teachers who are ready to ensure that the end product of the studies - the medical doctor - is a physician ready to respond to the demands and needs of the patients.

Authors' contributions: Conception and design, Acquisition, analysis and interpretation of dana, Drafting the article: SP and RG; Revising it critically for important intellectual content: RG

Conflict of interest: The authors declare that they have no conflict of interest. This article was not sponsored by any external organisation.

\section{References}

1. Jureša V, Jurković $D$, Katić M, Gmajnić R, Diminić Lisica I, et al. Model unaprjeđenja preventivne zdravstvene zaštite koju pruža hrvatska djelatnost obiteljske medicine. U: Šogorić S, Štimac D, editors. Knjiga sežetaka. Zagreb: Hrvatsko društvo za javno zdravstvo; 2010. p. 181-191.

2. Katić M, Rumboldt M, Materljan E, Gmajnić R. Analiza stanja u obiteljskoj medicini u Hrvatskoj i nužnost promjena. Medix: specijalizirani medicinski dvomjesečnik. 2009;15(80/81);51-6.

3. Katić M, Budak A, Ivanković D, Mastilica M, Lazić D, Babić-Banaszak A, et al. Patients' views on the professional behaviour of family physicians. Fam Pract. 2001;18(1):42-7.

4. Gmajnić R, Pribić S, Petrić, D. Prijedlog regionalne organizacije primarne zdravstvene zaštite. Medicina familiaris Croatica. 2008;16; 32-6.
5. Gmajnić R, Ebling Z. Primarna zdravstvena zaštita u Osijeku - razvoj i postignuća. Medicinski vjesnik. 2009;41(3-4);57-60.

6. Marusic M. War and medical education in Croatia. Acad Med. 1994;69(2):111-3.

7. Puntarić D, Brkić K. Formation and organization of military medical service at the east Slavonia front in the 1991/1992 war in Croatia. Mil Med. 1995; 160(8):412-6.

8. Markeljević J, Lacković Z. The case of Croatian hospitals: Is this the end of humanitarian rules? Medicine and War. 1994;10(1);50-62.

9. Ebling Z, Santo T, Mandić N, Glavina K, Serić V, Laufer D. Osijek Health Center during the 19911992 war in Croatia. Mil Med. 2000;165(12):929-34.

10. Rogulj ZM, Baloevic E, Dogas Z, Kardum G, Hren D, Marusic A, et al. Family medicine practice and research: survey of physicians' attitudes towards scientific research in a post-communist transition country. Wien Klin Wochenschr. 2007;119:164-9.

11. Hren D, Sambunjak D, Ivanis A, Marusic M, Marusic A. Perceptions of authorship criteria: effects of student instruction and scientific experience. J Med Ethics. 2007;33:428-32.

12. Marusic A, Marusic M. Teaching students how to read and write science: a mandatory course on scientific research and communication in medicine. Acad Med. 2003;78:1235-9.

13. Simunovic VJ, Petkovic M, Miscia S, Petrovic M, Stallaerts R, Busselmaier W, et al. Short history of a just mentorship and support. Croat Med J. 2008;49:18-22.

14. Zerem E, Delibegovic S. Prof. Marusic placed his editorial board at the disposal of the postgraduate students of Tuzla University School of Medicine. Croat Med J. 2008;49:101.

15. Gluncic V, Pulanic D, Prka M, Marusic A, Marusic M. Curricular and extracurricular activities of medical students during war, Zagreb University School of Medicine, 1991-1995. Acad Med. 2001;76:82-7.

16. Pribić S, Krolo V, Ćosić, I. Gmajnić R, Lukić, M. Results: of education of primary health care physicians for the management of the private care offices in Croatia. 16th Wonca Europe Conference "Family Medicine into the Future - Blending Health and Cultures", Malaga, Španjolska, 2010; p. 253-4. 